\title{
Can nutritional status influence the quality of life of cancer patients? ${ }^{1}$
}

\author{
O estado nutricional pode influenciar a qualidade \\ de vida de pacientes com câncer?
}

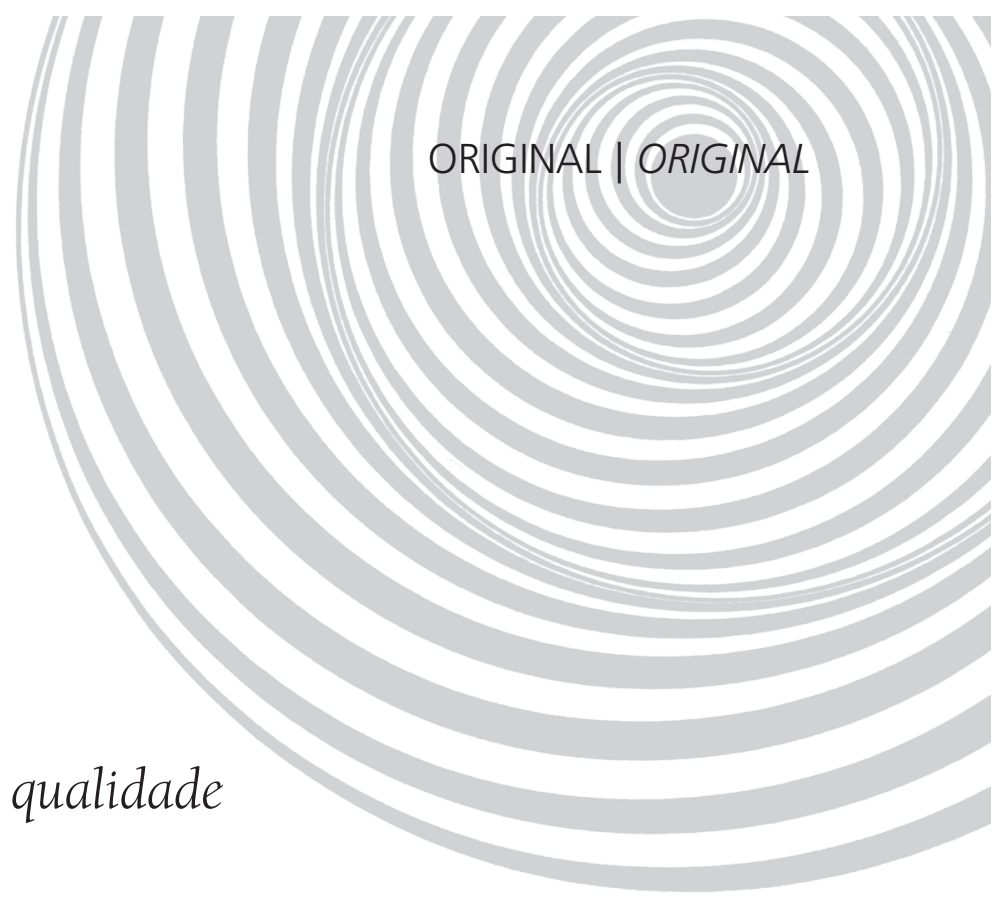

Lúcia Rota BORGES²

Silvana Iturriet PAIVA²

Denise Halpern SILVEIRA ${ }^{3}$

Maria Cecília Formoso ASSUNÇÃO ${ }^{4}$

Maria Cristina GONZALEZ ${ }^{4}$

A B S T R A C T

\section{Objective}

This study aimed to evaluate the influence of nutritional status on the quality of life of a cohort of cancer patients submitted to chemotherapy.

\section{Methods}

Patients receiving chemotherapy for the first time in a University Hospital in Pelotas (RS), Brazil, were evaluated prospectively. Their nutritional risk was determined by the Patient-Generated Subjective Global Assessment scores and their quality of life by the World Health Organization's quality of life questionnaire, administered at the beginning and end of the study.

\section{Results}

One hundred and forty-three patients were studied, $76.2 \%$ being females. The prevalence of malnutrition at baseline was $14.0 \%$. The present study found that malnourished patients had a poor quality of life. The nutritional risk of $41.6 \%$ of the patients increased after chemotherapy. A significant association was found between the presence of symptoms and increased nutritional risk $(p<0.001)$. Additionally, there was a significant negative correlation between physical domain and nutritional risk scores, showing that quality of life increases as nutritional risk decreases.

\footnotetext{
1 Artigo elaborado a partir da dissertação de L.R. BORGES, intitulada "Fatores determinantes da qualidade de vida em uma coorte de pacientes submetidos à quimioterapia". Universidade Católica de Pelotas; 2008.

2 Universidade Católica de Pelotas, Programa de Pós-Graduação em Saúde e Comportamento. R. Almirante Barroso, 1202, Sala G, 109, 96010-208, Pelotas, RS, Brasil. Correspondência para/Correspondence to: L.R. BORGES. E-mail: <luciarotaborges@yahoo.com.br>.

3 Universidade Federal do Rio Grande, Programa de Pós-Graduação em Ciências da Saúde. Pelotas, RS, Brasil.

${ }^{4}$ Universidade Federal de Pelotas, Programa de Pós-Graduação em Epidemiologia. Pelotas, RS, Brasil.
} 
746 | L.R. BORGES et al.

\section{Conclusion}

Nutritional risk is inversely associated with quality of life in cancer patients after chemotherapy. Early nutritional interventions could minimize the side effects of treatment with a positive impact on quality of life.

Indexing terms: Nutritional status. Neoplasm. Quality of life. Drug therapy.

\section{R E S U M O}

\section{Objetivo}

Avaliar a influência do estado nutricional sobre a qualidade de vida em uma coorte de pacientes submetidos à quimioterapia.

\section{Métodos}

Avaliaram-se prospectivamente pacientes em quimioterapia de um hospital universitário de Pelotas (RS), Brasil. O estado nutricional foi avaliado por meio dos escores obtidos pela Avaliação Subjetiva Global Produzida Pelo Paciente e a qualidade de vida foi avaliada a partir da versão abreviada do questionário de qualidade de vida da Organização Mundial da Saúde. A Avaliação Subjetiva Global Produzida Pelo Paciente e o questionário de qualidade de vida foram aplicados no início e no final do estudo.

\section{Resultados}

Foram avaliados 143 pacientes, dos quais 76,2\% eram mulheres. A prevalência de desnutrição na avaliação inicial foi de 14,0\%. Observou-se que, tanto no início quanto no final do estudo, os pacientes desnutridos apresentaram pior qualidade de vida. Houve aumento do risco nutricional em 41,6\% dos pacientes. Foi encontrada associação significativa entre a presença de sintomas e o aumento do risco nutricional $(p<0,001)$. Além disso, houve correlação negativa estatisticamente significativa entre a variação dos escores do domínio físico e risco nutricional, evidenciando que conforme o risco nutricional diminui, melhora a qualidade de vida.

\section{Conclusão}

Conclui-se que as modificações no risco nutricional estão associadas a mudanças na qualidade de vida em pacientes com câncer. Sugere-se que o acompanhamento multidisciplinar desses pacientes poderia minimizar os efeitos colaterais do tratamento, diminuindo o risco de desnutrição, com repercussões positivas na qualidade de vida.

Termos de indexação: Estado nutricional. Neoplasia. Qualidade de vida. Quimioterapia.

\section{INTRODUCTION}

Malnutrition in cancer patients is frequently reported in the literature and found in almost 75\% of the patients at diagnosis. It is also significantly associated with increased morbidity and mortality, reduced response and tolerance to treatment, higher costs, diminished chances of survival and worse Quality Of Life $(\mathrm{QOL})^{1-3}$. Malnutrition is caused by several factors and may vary according to the type of tumor, its stage and treatment used $^{2,4,5}$.

Chemotherapy (CT) is a common cancer treatment and can affect the nutritional status of cancer patients. This effect may be due to the toxicity of the treatment, since traditional chemotherapeutic drugs are nonspecific, attacking healthy cells in addition to diseased cells, and setting off adverse effects that impact nutritional status, such as nausea, vomiting, constipation, diarrhea and others ${ }^{2,4-7}$.

Cancer, like other serious illnesses, may cause many changes in a person's life and the possible confrontation with imminent death may induce metabolic and lifestyle changes which may have a huge impact on $\mathrm{QOL}^{8-10}$.

The term "quality of life" has been defined by the World Health Organization (WHO) as the way an individual perceives his or her position in life, the cultural context and system of values he or she experiences in relation to his or her goals, expectations, standards and concerns ${ }^{10}$. 
Nutritional status and cancer treatment interact in a complex way and have a significant impact on $\mathrm{QOL}^{8,9}$. Although nutritional status during $\mathrm{CT}$ is one of most importance, few studies have addressed its impact on the QOL of cancer patients ${ }^{11}$

Hence, the aim of this study is to evaluate the influence of nutritional status on QOL in a cohort of patients undergoing CT.

\section{METHODS}

This study is a partial analysis of a longitudinal study done at the University Hospital of the Federal University of Pelotas (RS), Brazil which prospectively evaluated all patients aged 18 years or older undergoing CT for the first time between March 2004 and July 2005.

Gender, age, race, marital status, socioeconomic and anthropometric data were collected. The socioeconomic level was classified according to the Brazilian Association of Research Organizations (ABEP) criteria12 which investigates the ownership of appliances and other durable goods, presence of maids and education level of the head of the household. The resulting socioeconomic level varies from class A (richest) to class $\mathrm{E}$ (poorest).

Data on the diagnosis, type of CT and disease stage were obtained from the hospital's database. Staging allows one to estimate the probability of survival and plan the treatment ${ }^{13}$.

Nutritional status was assessed by the Patient-Generated Subjective Global Assessment (PG-SGA), through the administration of a questionnaire modified by Ottery ${ }^{14}$. This assessment tool is an adaptation of the Subjective Global Assessment (SGA) developed by Detsky ${ }^{15}$. Its main purpose is to provide a numerical score for nutritional risk - higher score means greater risk indicating the level of nutritional intervention required. It is also possible to use the PG-SGA to classify nutritional status into three categories: $A$ (well nourished), B (moderately or possibly malnourished) and C (severely malnourished) ${ }^{14}$.
The patients were weighted with a Filizola digital scale model PL 150 (150kg capacity, 100g precision) and measured with a $200 \mathrm{~cm}$ height rod $(1 \mathrm{~mm}$ precision) attached to the scale.

Quality of life was determined by the WHOQOL-BREF questionnaire. This is a short Portuguese version of the WHOQOL-100. It contains 26 questions grouped into four major domains (physical, psychological, social relations and environmental) and two general questions on overall QOL and general health status. The answers were given using a five-point Likert-type scale and were then converted into scores ranging from 0 to 100. Higher scores indicate better $\mathrm{QOL}^{16,17}$.

The QOL questionnaire was administered and nutritional status assessed on two different occasions: before the first $\mathrm{CT}$ cycle and before the last CT cycle.

Statistical analysis was done by the Stata 9.2 statistics package (StataCorp, Texas, USA). The Shapiro-Wilk test was used to verify the normality of the variables. Descriptive analysis was used to determine the means and respective standard deviations of the variables with normal distribution. A paired Student's $t$-test was used to compare the means of each section of the WHOQOL obtained at the start and end of CT, and analysis of variance was used to compare the difference in QOL scores for the different nutritional status categories. The Spearman's correlation coefficient was used to evaluate the correlations between the continuous variables with normal distributions. The $\chi^{2}$ test was used to test the association between symptoms and nutritional status. The predictive power of the sample was calculated retrospectively once the mean and standard deviations of the variables of interest had been established. The level of significance for all tests was set at $5 \%$.

This study was approved by the Research Ethics Committee of the Federal University of Pelotas School of Medicine. The patients signed the free and informed consent form on the first day of $\mathrm{CT}$. 


\section{RE S U L T S}

One hundred forty-three patients participated in this study. Their mean age was $M=56.6$ $\mathrm{SD}=12.8$ years. Most of them were females $(76.2 \%)$ and almost half were from the D/E socioeconomic levels (46.7\%). According to the PG-SGA administered at baseline, 86.0\% were well nourished and $14.0 \%$ were moderately or severely malnourished.

The most prevalent diagnoses were breast and gynecological cancers (58.7\%) (Table 1). Most of the patients had stage II cancers $(46.5 \%)$ and $77.6 \%(n=111)$ received adjuvant or neoadjuvant CT (Table 1). Seventy-four patients $(51.8 \%)$ had undergone surgery before CT.

The clinical course of the patients during the study varied substantially secondary to their nutritional status. Only 4.4\% of the well nourished patients died or discontinued their treatment. Among the moderately or possibly malnourished patients, $43.8 \%$ died during the treatment and $14.6 \%$ could not finish the treatment. None of the severely malnourished patients could be reevaluated at the end of the treatment since $75.0 \%$ of them had died and $25 \%$ had discontinued the treatment because of a deteriorating health status.

The initial and final PG-SGA scores were compared to determine if the nutritional risk of the patients changed over the studied period. The results showed that the scores of $41.6 \% \quad(n=57)$ of the patients increased (i.e. greater nutritional risk), $13.9 \%(n=19)$ remained the same, and $44.5 \%(n=61)$ decreased (i.e. smaller nutritional risk).

Fifty-nine patients (41.3\%) experienced CT-related side effects. Table 2 shows the incidence of symptoms according to the PG-SGA.

The present study also investigated a possible association between side effects and nutritional status. The results showed that the nutritional status of $83 \%$ of the patients who experienced side effects got worse, in contrast with $15.5 \%$ of the patients who did not experience side effects $(p<0.001)$.
Table 1. Characteristics of the sample related to the disease. Pelotas (RS) Brazil, 2004-2005.

\begin{tabular}{lcc}
\hline Characteristics & $\mathrm{n}$ & $\%$ \\
\hline Site of primary tumor & & \\
Breast/gynecology & 84 & 58.7 \\
Head neck/gastrintestinal & 34 & 23.8 \\
Lung & 11 & 7.7 \\
Others sites $^{1}$ & 14 & 9.8 \\
Tumor stage $^{2}$ & & \\
I & 6 & 4.2 \\
II & 66 & 46.5 \\
III & 50 & 35.2 \\
IV & 20 & 14.1 \\
Type of chemotherapy & & \\
Neo-adjuvant/adjuvant & 111 & 77.6 \\
Palliative & 22 & 15.4 \\
Curative & 10 & 7.0 \\
\hline
\end{tabular}

1 Others sites: 8 hematological; 2 unknown primary site; 1 bladder; 1 multiple myeloma; 2 testicle. ${ }^{2}$ One patient had an unknown tumor stage.

Table 2. Presence of symptoms related by patients at the end of the study. Pelotas (RS) Brazil, 2004-2005.

\begin{tabular}{llc}
\hline Symptoms & $\mathrm{n}^{1}$ & $\%$ \\
\hline Dry mouth & 34 & 23.8 \\
Lack of appetite & 26 & 18.2 \\
Early satiation & 26 & 18.2 \\
Nausea & 25 & 17.5 \\
Food smells are unpleasant & 21 & 14.7 \\
Constipated & 15 & 10.5 \\
Mouth ulcers & 13 & 9.1 \\
Pain & 12 & 8.4 \\
Food tastes strange & 12 & 8.4 \\
Vomiting & 8 & 5.6 \\
Problems of swallowing & 5 & 3.5 \\
\hline
\end{tabular}

${ }^{1}$ Values overcome $100 \%$ because patients could have more than one symptom.

Table 3. Mean scores for quality of life (physical, psychological, social relationships, environment domains and overall quality of life and general health) before and after chemotherapy. Pelotas (RS) Brazil, 2004-2005.

\begin{tabular}{|c|c|c|c|c|c|}
\hline \multirow{2}{*}{ Domains of $\mathrm{WHOQOL}$} & \multicolumn{2}{|c|}{ Before $\mathrm{CT}^{1}$} & \multicolumn{2}{|c|}{ After CT } & \multirow[t]{2}{*}{$p^{2}$} \\
\hline & $\mathrm{M}$ & SD & $\mathrm{M}$ & SD & \\
\hline \multicolumn{6}{|l|}{ Domains } \\
\hline Physical & 60.1 & 17.0 & 62.1 & 18.2 & 0.20 \\
\hline Psychological & 67.9 & 15.1 & 67.9 & 13.3 & 1.00 \\
\hline Social relationships & 75.9 & 15.5 & 72.8 & 16.1 & 0.06 \\
\hline Environment & 62.1 & 12.6 & 62.4 & 13.0 & 0.80 \\
\hline \multicolumn{6}{|l|}{ Questions } \\
\hline Overall quality of life & 71.4 & 17.4 & 72.9 & 15.4 & 0.30 \\
\hline General Health & 58.4 & 23.2 & 62.9 & 22.5 & 0.01 \\
\hline
\end{tabular}

M: mean; SD: standard deviation; ${ }^{1} \mathrm{CT}$, chemotherapy; ${ }^{2}$ Paired Student's $\mathrm{t}$ test, $p<0.05$ level. 
Table 3 shows the mean QOL scores before and after $C T$. Only general health increased significantly $(p=0.01)$.

Analysis of variance was performed to detect variations in the different $\mathrm{QOL}$ domains, according to the nutritional status categories obtained at the beginning and end of the study. The results are shown in Figures 1 and 2 . Malnourished patients had lower baseline QOL scores in all domains, but only their physical scores were significantly lower than those of wellnourished individuals. At the end of the study, malnourished patients had significantly lower QOL scores in most domains, except for the social relations and environmental domains.

The present study also investigated the existence of a correlation between nutritional risk and QOL scores after treatment. A small, yet statistically significant negative correlation ( $r=-0.18$ ) was found $(p=0.03)$ for the physical domain, showing that QOL increases as nutritional risk decreases. There were no significant correlations for the other domains.

\section{DISCUSSION}

Many factors contribute to worsen nutritional status, which in turn is associated with a worse prognosis and has a direct but not very well documented impact on the QOL of cancer patients. Some studies have demonstrated that the scores of malnourished patients in QOL assessments were worse than those of wellnourished patients ${ }^{10,18,19}$. This study aimed to show

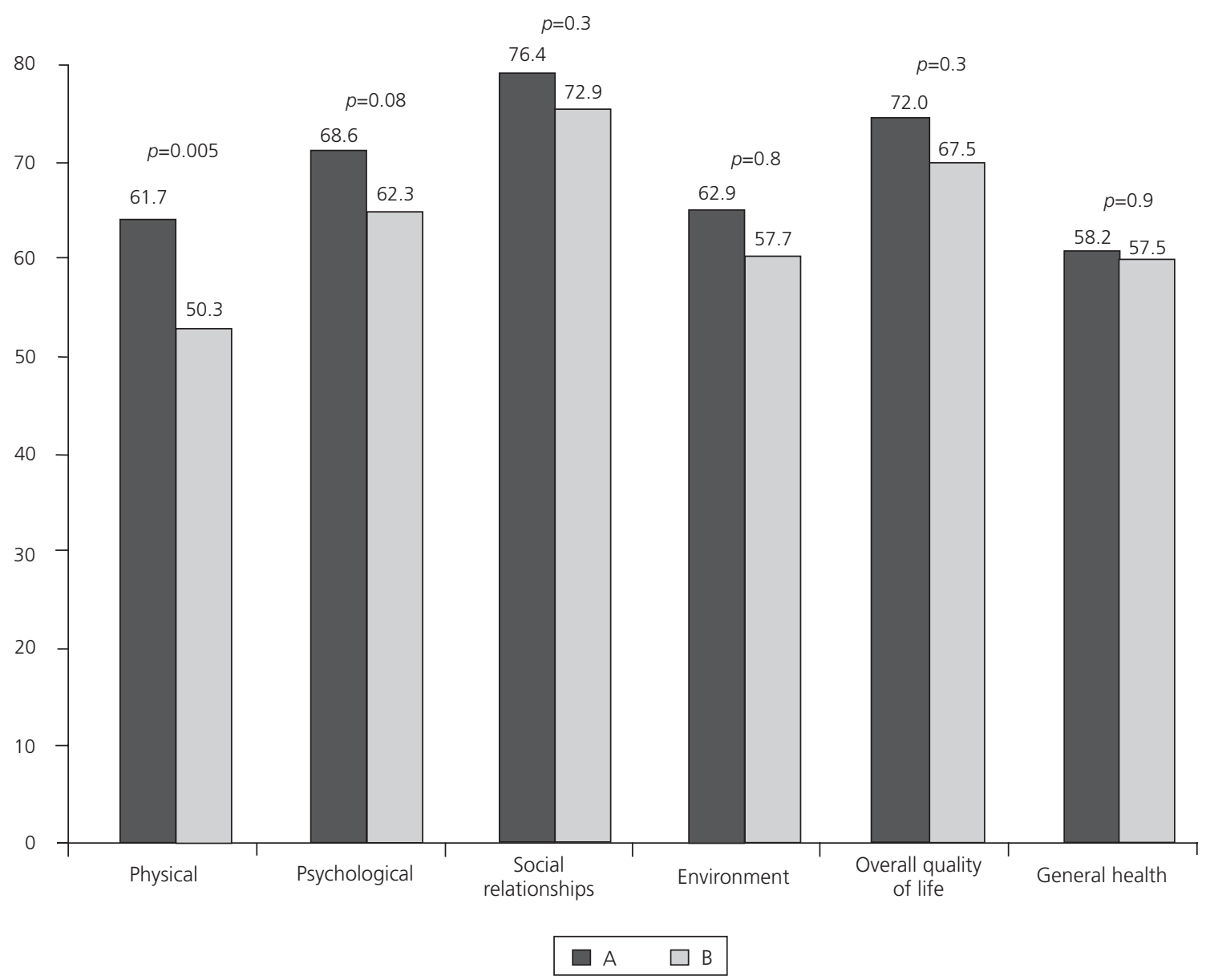

Figure 1. Quality of life scores by domain according to baseline nutritional status. Pelotas (RS) Brazil, 2004-2005. 


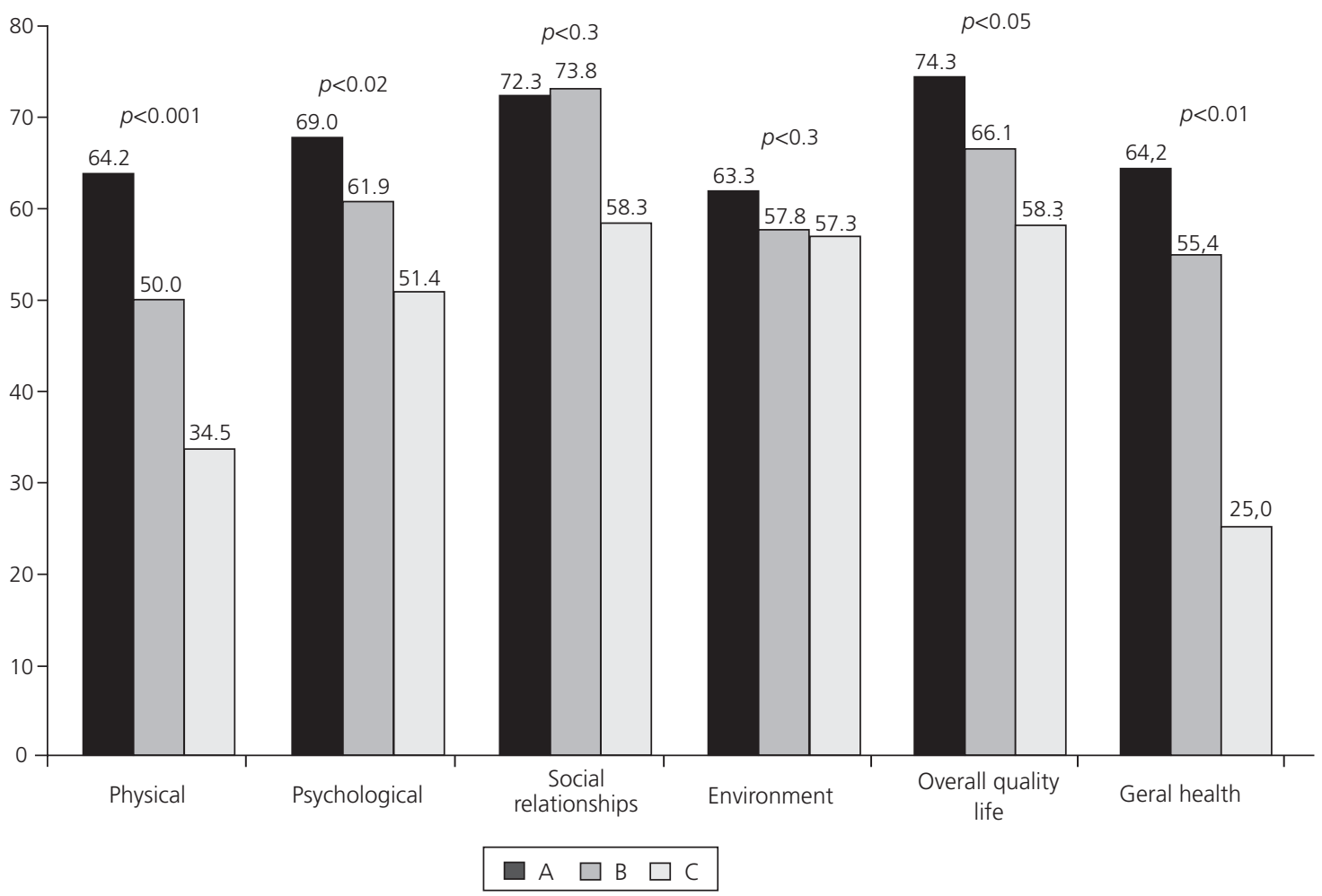

Figure 2. Quality of life scores by domain according to nutritional status at the end of the study. Pelotas (RS) Brazil, $2004-2005$.

the influence of nutritional status on the QOL of a cohort of cancer patients.

Most of the participants of this study were female or older than sixty years. This is due to the types of cancer presented by the cohort: breast and cervical cancers (most common cancers in females), followed by cancers of the head and neck and gastrointestinal tract (more common in older patients).

This study found that only $14.0 \%$ of the patients had some degree of malnutrition at the time of diagnosis. This may be explained by the high prevalence of breast cancer in this sample $(58.7 \%)$, a type of cancer that is usually not associated with cachexia. The study also found that all patients who were severely malnourished at baseline either died or discontinued the treatment, which explains why they did not undergo the second assessment and were excluded from this sample. CT treatment was discontinued when the patient's health declined rapidly. This demonstrates the importance of nutritional status for the prognosis of cancer patients submitted to $\mathrm{CT}$.

PG-SGA seems to be a more sensitive nutritional assessment method suitable for longitudinal studies since it enables the early detection of small changes in nutritional status over short periods ${ }^{20}$. This was evidenced by this study, since the risk of malnutrition increased for $41.6 \%$ of the patients, that is, their final PG-SGA score was greater than their baseline score.

The early identification of CT-related side effects and their appropriate management may help to reduce their impact on the patient's nutritional status. In this study, $41.3 \%$ of patients reported some type of side effect at the end of the studied period, with dry mouth being the most common, followed by lack of appetite, early satiety and nausea. A Spanish study of cancer patients showed that the most common complaints were loss of appetite (42.2\%) and 
early satiety $(21.5 \%)^{21}$. Since the PG-SGA enabled early detection of side effects, the institution of appropriate nutritional and pharmacological measures prevented further deterioration of nutritional status.

QOL assessment has been used as an important tool for studying the impact of disease, drawing up indicators of disease severity and course and predicting treatment efficiency ${ }^{22}$. In oncology, the patient's general health status directly impacts QOL, which, in turn, is influenced by a broad range of nutritional factors ${ }^{23}$. Furthermore, some authors have shown that poor nutritional status is indicative of worse QOL ${ }^{19,24}$. A recent study has shown that a weight loss in excess of $10 \%$ of the body weight is significantly associated with all the main QOL domains and with symptoms such as fatigue, nausea, pain, loss of appetite and changes in bowel habits ${ }^{25}$.

Analysis of the different QOL domains suggests that the physical domain and general health improve after CT. However, only general health scores increased significantly. Contrary to our findings, an analysis of the QOL of 40 patients with colorectal cancer showed that the physical and psychological scores after CT decreased significantly ${ }^{26}$. Boery ${ }^{27}$ also used the WHOQOLBREF questionnaire to assess the QOL of patients with lung neoplasms before and after $\mathrm{CT}$ and found that psychological scores decreased significantly. According to this author, the diagnosis and stress caused by the disease are already enough to promote changes, especially psychological changes. Social relations tended to worsen after $\mathrm{CT}$, but the decrease was not statistically significant.

Assessment of QOL scores against nutritional status showed that malnourished patients had lower QOL scores before and after $C T$, mainly in the physical and psychological domains, as well as worst overall QOL and general health scores. Gupta et al. ${ }^{19}$ also investigated the association between nutritional status and QOL in 58 patients with colorectal cancer with the QLQ-C30 questionnaire and found that well- nourished patients have a better $\mathrm{QOL}$, that is, better scores in the general health and physical domains. According to these authors, malnutrition is directly associated with lower QOL. Another study with 152 gastrointestinal cancer patients found that the malnourished patients had lower QOL scores, responded more poorly to $\mathrm{CT}$ and had a shorter life expectancy ${ }^{28}$. On the other hand, Hammerlid et al. ${ }^{29}$ found that the QOL scores of well-nourished patients with head and neck cancers did not differ from those of malnourished patients. These results may be explained by the small sample size (48 patients) of that study.

The significant negative correlation found between the PG-SGA and physical domain scores suggests that QOL improves as the risk of malnutrition decreases. Another study found significant correlations between changes in nutritional status and $\mathrm{QOL}$, suggesting that improvements in nutritional status may also lead to improvements in $\mathrm{QOL}^{18}$.

One great difficulty in determining how cancer patients respond to nutritional interventions is that the metabolic changes induced by the disease make it difficult to value weight gain or improvement in the physical condition of these patients.. However, the results of this study show that QOL assessment may constitute an alternative and more sensitive tool for assessing the benefits of such interventions. A number of studies have assessed how nutritional interventions influence QOL. One study involving 125 radiotherapy patients concluded that nutritional counseling had a positive impact on various $\mathrm{QOL}$ aspects in cancer patients ${ }^{30}$. Peltz et al. ${ }^{31}$ studied how dietary supplementation affected QOL and found that QOL scores increased in the supplemented group, showing that improved nutritional status had a positive influence on QOL.

It would be interesting to determine which types of tumor and CT impact QOL most. The low statistical power of the present study limited subgroup analysis. Another limitation may have been the type of questionnaire used for $\mathrm{QOL}$ 
assessment. A generic questionnaire validated for the Brazilian population was used because back then there were no other validated questionnaires in Portuguese, specific for cancer patients (EORTC QLQ (-30). Nevertheless, other studies have shown congruent results, regardless of the type of QOL questionnaire used, and the impact of nutritional status on cancer patients should be assessed ${ }^{30}$

\section{CONCLUSION}

Cancer patients receiving $\mathrm{CT}$ require multidisciplinary care, especially with regard to nutrition. Nutritional support could minimize treatment side effects and reduce the risk of malnutrition. This preventive measure would also have a positive impact on QOL. Therapeutic and nutrition guidelines based on a better understanding of the relationship between nutritional status and QOL should be included in the treatment protocol of cancer patients. Furthermore, improved QOL should be considered an important outcome for these patients after any nutritional intervention.

\section{COLLABORATORS}

L.R. BORGES coordinated the study. L.R. BORGES and M.C. GONZALEZ conceived the study, performed the statistical analyses and wrote the manuscript. S.I. PAIVA and D.H. SILVEIRA collected the data. M.C.F. ASSUNÇÃO helped to conceive the study and reviewed the final manuscript.

\section{REFERENCES}

1. Gómez-Candela C, Luengo LM, Cos Al, MartínezRoque $\mathrm{V}$, Iglesias C, Zamora $\mathrm{P}$, et al. Valoración global subjetiva en el paciente neoplásico. Nutr Hosp. 2003;18(6):353-7.

2. Jatoi A, Loprinzi CL. An update: cancer-associated anorexia as a treatment target. Curr Opin Clin Nutr Metab Care. 2001; 4(3):179-82.

3. Bauer J, Capra S, Ferguson M. Use of the scored Patient-Generated Subjective Global Assessment
(PG-SGA) as a nutrition assessment tool in patients with cancer. Eur J Clin Nutr. 2002; 56(8):779-85.

4. Wojtaszek CA, Kochis LM, Cunningham RS. Nutrition impact symptoms in the oncology patient. Oncol Issues. 2002; 17(2):15-7.

5. Stratton RJ, Green CJ, Elia M. Disease-related Malnutrition: an evidence-based approach to treatment. Wallingford: CABI Publishing; 2003.

6. Malzyner A, Caponero R. Conseqüências nutricionais do tratamento quimioterápico. In: Waitzberg DL, editor. Dieta, nutrição e câncer. $2^{a}$ ed. São Paulo: Atheneu; 2006. v.1.

7. Paiva SMM. Avaliação da qualidade de vida de pacientes oncológicos em tratamento quimioterápico adjuvante [mestrado]. Ribeirão Preto: Universidade Federal de São Paulo; 2006.

8. Michelone APC, Santos VLCG. Qualidade de vida de adultos com câncer colorretal com e sem ostomia. Rev Latino-Am Enfermagem. 2004; 12(6): 875-83.

9. Ferrel BR, Dow KH, Grant M. Measurement of quality of life in cancer survivors. Qual Life Res. 1995; 4(6):523-31.

10. Nucci NAG. Qualidade de vida e câncer: um estudo compreensivo [tese]. Ribeirão Preto: Universidade Federal de São Paulo; 2003.

11. Ravasco P, Monteiro-Grillo I, Vidal PM, Camilo ME. Qualidade de vida em doentes com cancro gastrintestinal: Qual o impacto da nutrição? Acta Médica Portuguesa. 2006; 19(3):189-96.

12. Associação Brasileira de Empresas de Pesquisa. 2008. Disponível em: <http//www.abep.org>.

13. American Joint Committee on Cancer. American College of Surgeons. 2007. Available from: <http// www.cancerstaging.org.Chicago>

14. Ottery FD. Definition of standardized nutritional assessment and interventional pathways in oncology. Nutrition. 1996; 12(1 Suppl):S15-9.

15. Detsky AS, McLaughlin JR, Baker JP, Johnston N, Whittaker S, Mendelson RA, et al. What is subjective global assessment of nutritional status? JPEN. 1987; 11(1): 8-13.

16. The WHOQOL-Group. Versão em português dos instrumentos de avaliação de qualidade de vida (WHOQOL). Porto Alegre: Universidade Federal do Rio Grande do Sul; 1998. Disponível em: <http:// www.ufrgs.br/psiq>.

17. The WHOQOL Group. Development of the World Health Organization WHOQOL-BREF quality of life assessment. Psychol Med. 1998; 28(3):551-8.

18. Isenring E, Bauer J, Capra S. The scored Patientgenerated Subjective Global Assessment (PG-SGA) and its association with quality of life in ambulatory 
patients receiving radiotherapy. Eur J Clin Nutr. 2003; 57(2):305-9.

19. Gupta D, Lis CG, Granick J, Grutsch JF, Vashi PG, Lammersfeld CA. Malnutrition was associated with poor quality of life in colorectal cancer: a retrospective analysis. J Clin Epidemiol. 2006; 59(7): 704-9.

20. Barbosa-Silva MC, Barros AJ. Indications and limitations of the use of subjective global assessment in clinical practice: an update. Curr Opini Clin Nutr Metab Care. 2006; 9(3):263-9.

21. Segura A, Pardo J, Jara C, Zugazabeitia L, Carulla J, De Las Penas R, et al. An epidemiological evaluation of the prevalence of malnutrition in Spanish patients with locally advanced or metastatic cancer. Clin Nutr. 2005; 24(5):801-14.

22. Makluf ASD, Dias RC, Barra AA. Avaliação da qualidade de vida em mulheres com câncer de mama. Rev Bras Cancerol. 2006; 52(1):49-58.

23. Caro MM, Laviano A, Pichard C. Impact f nutrition on quality of life during cancer. Curr Opin Clin Nutr Metab Care. 2007; 10(4):480-7.

24. Ravasco P, Monteiro-Grillo I, Vidal PM, Camilo ME. Cancer: disease and nutrition are key determinants of patients' quality of life. Support Care Cancer. 2004; 12(4):246-52.

25. Nourissat A, Vasson MP, Merrouche $Y$, Bouteloup C, Goutte M, Mille D, et al. Relationship between nutritional status and quality of life in patients with cancer. Eur J Cancer. 2008; 44(9):1238-42.
26. Roque VM, Forones NM. Avaliação da qualidade de vida e toxicidade em pacientes com câncer colorretal tratados com quimioterapia adjuvante baseada em fluoropirimidinas. Arq Gastroenterol. 2006; 43(2): 94-101.

27. Boery EM. Qualidade de vida de pacientes adultos com câncer de pulmão submetidos a quimioterapia ambulatorial [tese]. São Paulo: Universidade Federal de São Paulo; 2003.

28. Persson C, Glimelius B. The relevance of weight loss for survival and quality of life in patients with advanced gastrointestinal cancer treated with palliative chemotherapy. Anticancer Res. 2002; 22(6B):3661-8.

29. Hammerlid E, Wirblad B, Sandin C, Mercke C, Edström S, Kaasa S, et al. Malnutrition and food intake in relation to quality of life in head and neck cancer patients. Head Neck. 1998; 20(6): 540-8.

30. Ravasco P, Monteiro-Grillo I, Camilo ME. Does nutrition influence quality of life in cancer patients undergoing radiotherapy? Radiother Oncol. 2003; 67(2):213-20.

31. Peltz G. Nutritional support in cancer patients: a brief review and suggestion for standard indications criteria. Nutr J. 2002; 1:1.

Received on: 20/10/2008

Final version resubmitted on: 27/7/2009

Approved on: 4/5/2010 
